\title{
The 1972 National Economic Plan: An Experiment in Fiscal Activism
}

\author{
by KEITH M. CARLSON
}

T

HE NATYONAL economic plan for the eighteen month period ending June 30,1973 has been presented to Congress and the public. The Administration's plan is presented in the form of three doctments - the Federal Budget, the Economic Report of the President, and the Annual Report of the Council of Economic Advisers. ${ }^{1}$ Included in these documents is a proposed Federal budget program designed to be consistent with targets for total spending (GNP), output, prices, and employment. General recommendations are also made for the role of monetary actions by the Federal Reserve System in the overall economic plan.

The goals for the U.S. econony in the months ahead are stated most explicitly by the Council of Economic Advisers (CEA) in their Annual Report." The goals consist of a reduction in the annual rate of inflation to less than 3 percent by the end of 1972 , and a reduction of unemployment to near 5 percent of the civilian labor force by the end of the year. The Administration believes that to achieve these targets an increase in total spending for goods and services (GNP) of 10.5 to 11 percent for the year ending fourth quarter 1972 is required. This rapid increase in total spending is to be facilitated by an increase in Federal expenditures of about 11 percent, reductions in tax rates attributable primarily to the Revenue Act of 1971 , and "[a]n abundant supply of money and other liquid assets and favorable conditions in money markets . .."

1 The Budget of the United States Government, Fiscal Year Ending June 30, 1973 (Government Printing Office, 1972), and Economic Report of the President, together with The Annual Report of the Council of Economic Advisers (Government Printing Office, 1972).

21972 CEA Report, Chapter 3.

IIbid., p. 106.
This article analyzes the Administration's national economic plan within the context of the St. Louis model.* First, the 1971 economic plan is compared with the record to obtain some perspective. Then the 1972 economic plan is examined in terms of feasibility and internal consistency. Since the evaluation is conducted with reference to the St Louis model, the conclusions refect the particular characteristics of that model. 5

\section{Evaluation of the 1971 Economic Plan}

Confronted with unacceptably rapid inflation, high unemployment and a continuing deterioration of our balance-of-payments position, the Administration announced several major policy changes on August 15, 1971. Included were suspension of the convertibility of the dollar into gold and other reserve assets, imposition of a surcharge on imports, a proposed removal of the Federal excise tax on automobiles, and introduction of a system of mandatory price-wage controls.

The announcement of these policy changes reflected obvious dissatisfaction with the course of the economy as it appeared at that time. In February the Administration had laid out a very ambitious set of economic goals, and apparently by late summer was convinced that sufficient progress was not being made toward

\footnotetext{
*The focus of this article is on the stabilization aspects of the Administration's economic program. The program is actually much broader in scope, involving discussion of resource allocation, incone distribution, and international economic aflaits.

"Leonall C. Andersen and Keith M. Carlson, "A Monetarist Model for Econonic Stabilization," this Review (April 1970), pp. $7-25$.

fiFor an economic review of 1971 , see Norman N, Bowsher, "1971 - Year of Recovery and Controls," this Review (December 1971), pp. 2-10.
} 
their achievement, ${ }^{7}$ The purpose of the following section is to determine the source of the discrepancy between the Administration's economic plan and the actual course of the economy. ${ }^{8}$

\section{Economic Goals ws. Realizations}

The CEA Report of a year ago projected a 9 percent increase in total spending from 1970 to 1971 . The actual increase was 7.5 percent. This error of 1.5 percent was the largest since the CEA underestimated GNP in 1966 by 1.7 percent. Although the 1971 error was relatively large by recent standards, it actually was small when compared to the last forecast made for a full expansion year following a recession, that is, 1962 (see Table I),

tawle

CEA Plolection Accuracy of Total Spending (GNPI

\begin{tabular}{|c|c|c|c|}
\hline & Trojected & $\begin{array}{l}\text { Actual } \\
\text { Change }\end{array}$ & \\
\hline 1962 & $9.4 \%$ & $6,7 \%$ & $27 \%$ \\
\hline 1963 & 4.4 & 5.4 & 410 \\
\hline 1064 & 6,5 & 6.6 & 0.1 \\
\hline 1965 & 61 & 7.5 & $4,1.4$ \\
\hline 1966 & 6.9 & 8.6 & 147 \\
\hline 1067 & 6.4 & 5.6 & 0.8 \\
\hline 1068 & 78 & 90 & 112 \\
\hline 1069 & 7.0 & 77 & 0.7 \\
\hline 1970 & $5 \%$ & 4.9 & 08 \\
\hline 1071 & 9.0 & 7.5 & 1.5 \\
\hline 6,10 & & & 14 \\
\hline
\end{tabular}

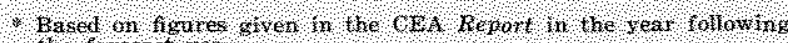
the romegt

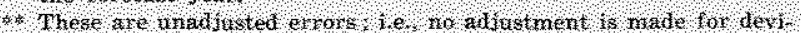

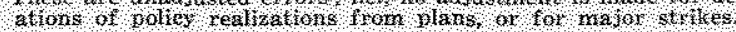

A comparison of the actual changes in the components of GNP for 1971 with the CEA projections (see Table II) indicates that the primary source of error was an overestimation of personal consumption by about $\$ 12$ billion. The CEA also overestimated the accumulation of business inventories and net exports. Somewhat surprisingly perhaps, the CEA underestimated the increase in business fixed investment as well as Federal purchases.

The 1971 CEA Report attracted more attention among professional economists than other reports of recent years. See the articles on the 1971 Report by M. J. Bailey, A. Eisner, A. P. Lerner and J. L. Stein in The American Economic Re view (September 1971 ), pp. 517-37, and $O$. H. Brownlee,

"The Economic Report of the President, 1971," Joumal of Money, Credit and Banking (November 1971), pp 833-39.

RFor a discussion of the $197 \mathrm{l}$ economic plan as it was originally presented, see Keith M. Carlson, "The 1971 National Ecom nonic Plan," this Review (March 1971), pp. 11-19.

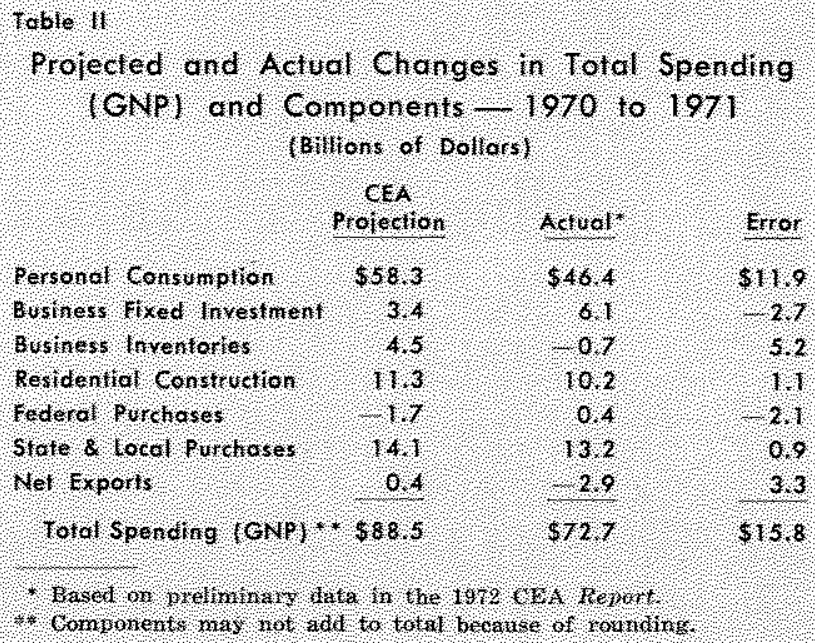

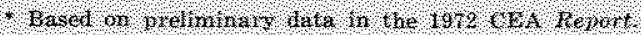

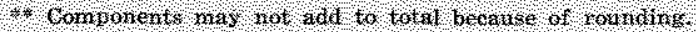

The 1971 projections for real product, prices, and unemployment were closely tied with the total spending projection (see Table III). In early 1971, the CEA believed that forces had been set in motion to reduce the inflation rate quickly and significantly so that the expected rapid advance of total spending could be manifested in a sharp increase in real product and an associated decline in unemployment.

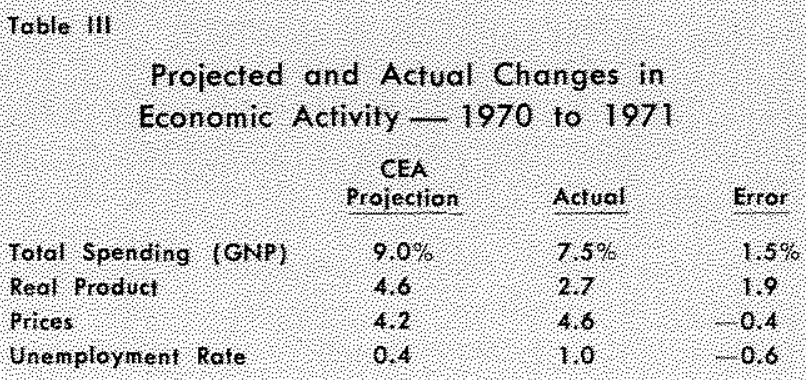

Table III shows that the CEA projected an increase in real product of 4.6 pereent; the actual increase was 2.7 percent. Unemployment was expected to average above the 1970 level of 4.9 percent, but was projected to decline from 6 percent early in 1971 to below 5 percent of the labor force by late in the year. Unemployment held steady near 6 percent during the year. And finally, prices were expected to slow to a 4.2 percent rate of advance. Prices rose 4.6 percent from 1970 to 1971 , even when the marked slowdown in prices in the second half of the year (reflecting pricewage controls) was included.

\section{Policy Plans vs. Realizations}

As a first step in examining the source of error underlying the CEA projections for 1971, policy plans are compared with realizations. Table IV gives planned and actual changes in the NIA budget from 


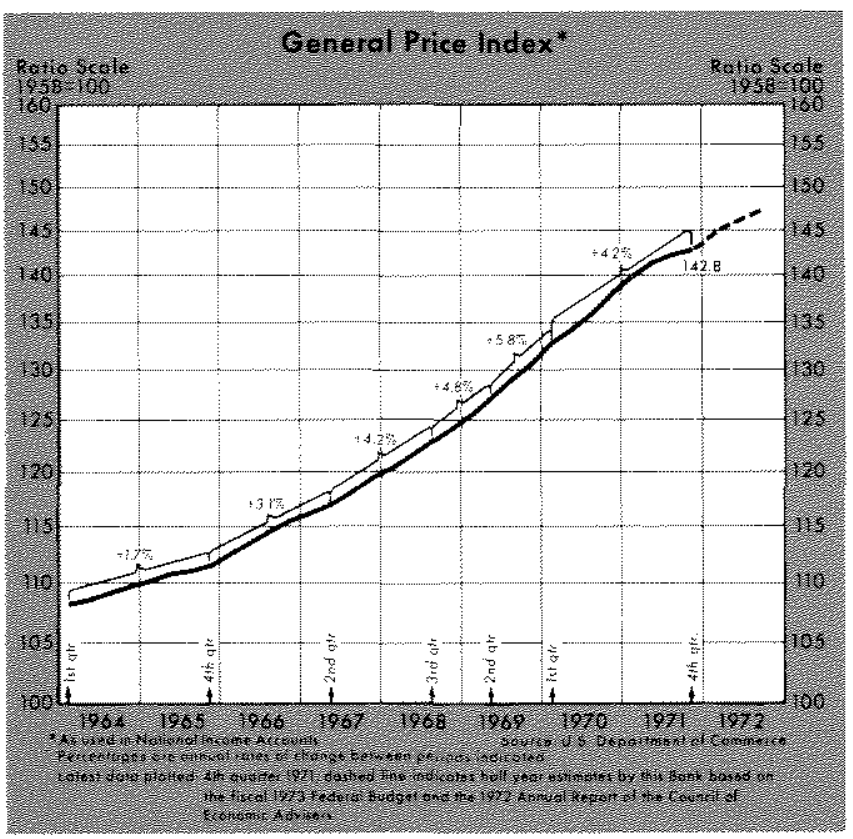

1970 to 1971 on both an actual and a high-employment (that is, cyclically adjusted) basis. ${ }^{3}$ From the standpoint of examining fiscal plans after the fact, the high-employment budget is more relevant than the NIA budget because it nets out the influence of GNP

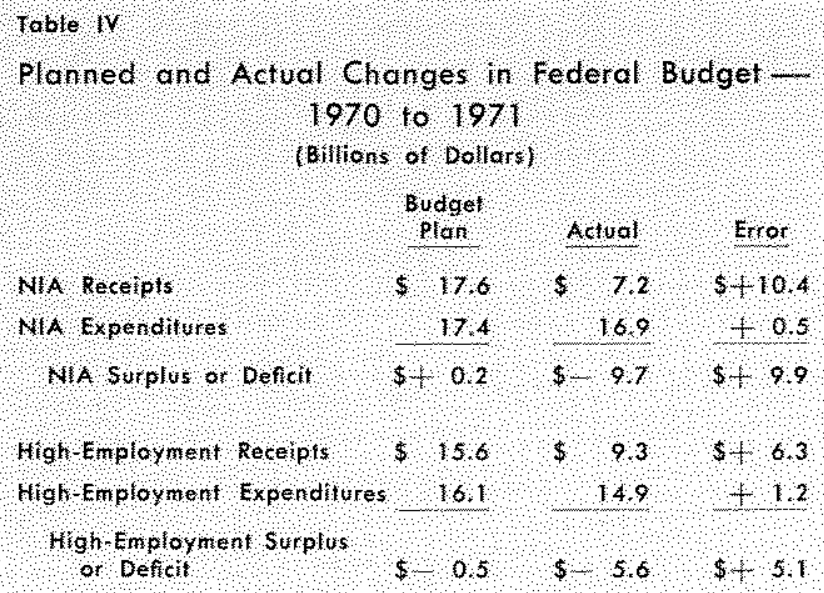

Notet tederal budket bans for 1971 were entimated by this bank atte yublished in the quarterly zelease e Federal Budget Trends, prepted by this Bank on Febriaty 20,1971

forecasting error on the movement of budget receipts and expenditures. On a high-employment basis the CEA underestimated the size of the fiscal stimulus; there was more fiscal stimulus than planned as the high-employment budget registered a surplus of $\$ 5.1$

"All references to the high-employment budget are estimates prepared by this Bank. For details on this Bank's procedures for estimating the high-employment budget, see "Technical Votes on Estimating the Hiyh-Employment Badget," available on request from the Research Department of this Bank. billion less than called for by the budget plan of early 1971. The source of this stimulus is traceable to a combination of factors including a planned increase in the social security tax base which was not implemented, a larger than planned increase in social security benefits, and policy changes of the Administration's own making as associated with the August 15 policy announcement.

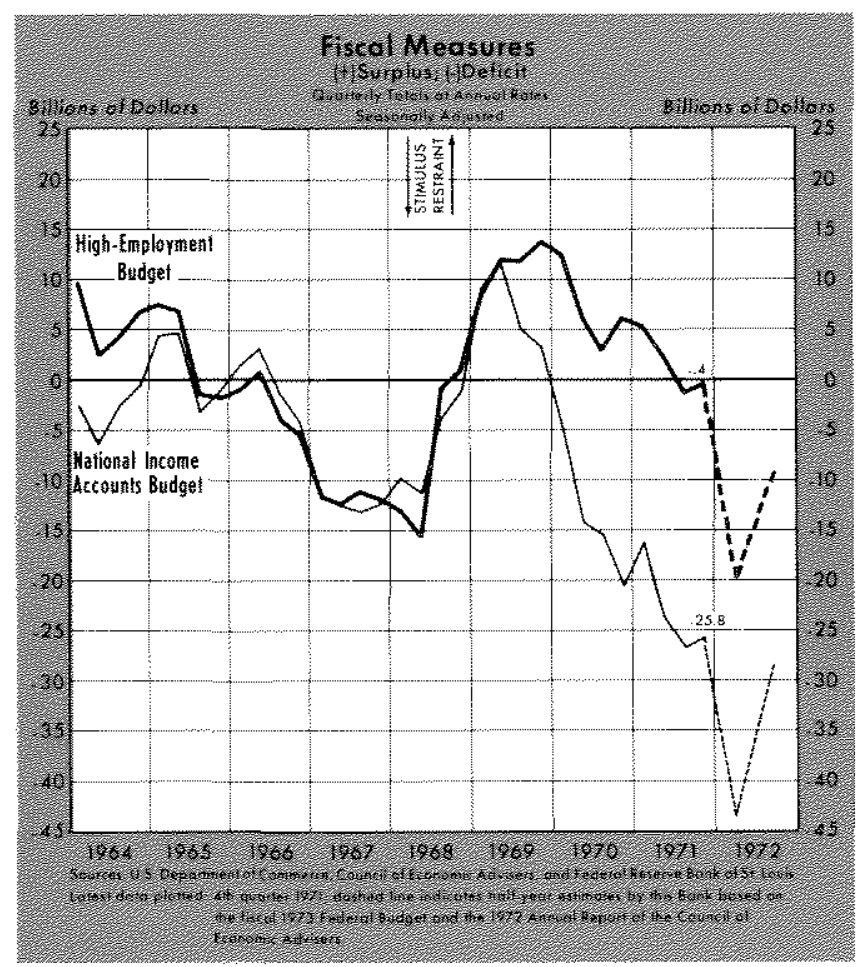

The CEA assumption about monetary actions in 1971 was never made perfectly explicit. Based on amplifying statements by CEA members to the press and in testimony before Congress, a 6 percent expan. sion of money was considered the minimum necessary to achieve the CEA goals. The actual increase in money was 6 percent from late 1970 to late 1971 , although this increase for the year consisted of a rapid 10.3 percent rate of increase in the first 7 months, followed by essentially no growth in the last 5 months.

\section{Analysis Based on St. Loubs Modet}

The fact that the CEA projections of economic expansion in 1971 still proved overly optimistic, despite the fact that key policy variables actually showed more stimulus than planned, suggests that their economic plan was not internally consistent. To quantify the sources of error further, some alternative simulations with the St Louis model are presented. Two cases are considered: estimates based on (1) changes in money 


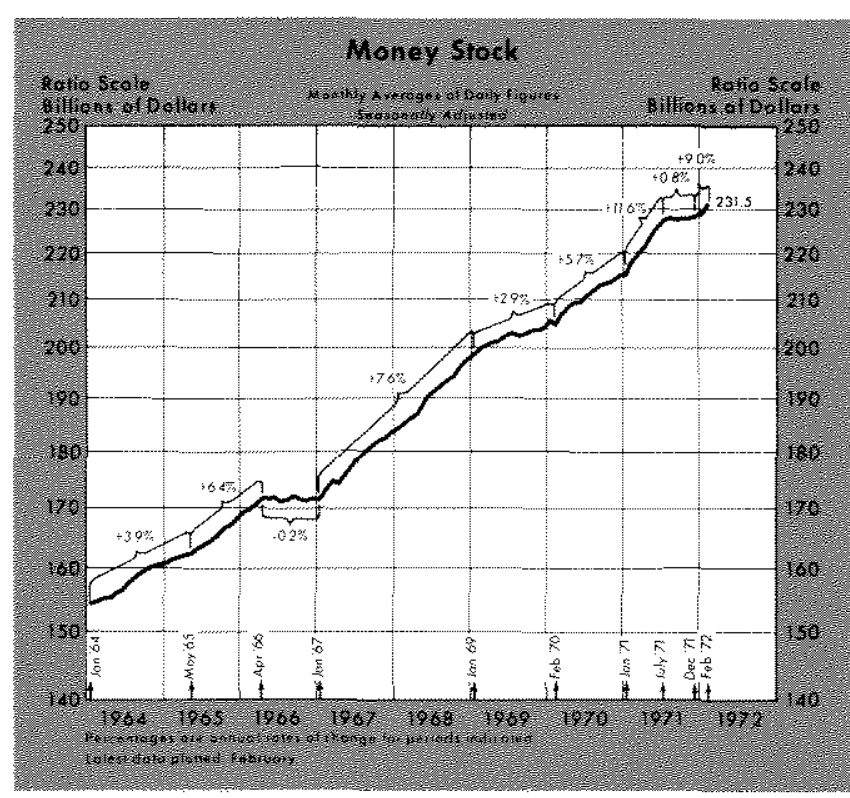

and expenditures as assumed by the CEA in early 1971, and (2) actual changes in money and expenditures.

Table $\mathrm{V}$ indicates that the St. Louis model was not projecting a rise of total spending nearly as rapid as
Federal expenditures. It should be pointed out, however, that without price-wage controls, the St. Louis model probably would have underestimated the extent of inflation. The persistence of unemployment near 6 percent throughout the year was forecast quite accurately by the St. Louis model.

The CEA erred significantly in their forecast of total spending, real product, prices and unemployment in 1971. This error cannot be traced to less policy stimulus than planned. These observations suggest that the CEA economic plan for 1971 overestimated the expected impact of stimulus from proposed monetary and fiscal actions.

The actions of the Administration in announcing policy changes on August 15 indicated possible recognition of this error, but those policy changes also reflected a belief that conventional monetary and fiscal actions were not capable of reducing inflation in an acceptably short period of time. Even though the CEA recognized (in their 1972 Report) the slowdown of inflation through second quarter 1971, mandatory price-wage controls were introduced to accelerate the decline.

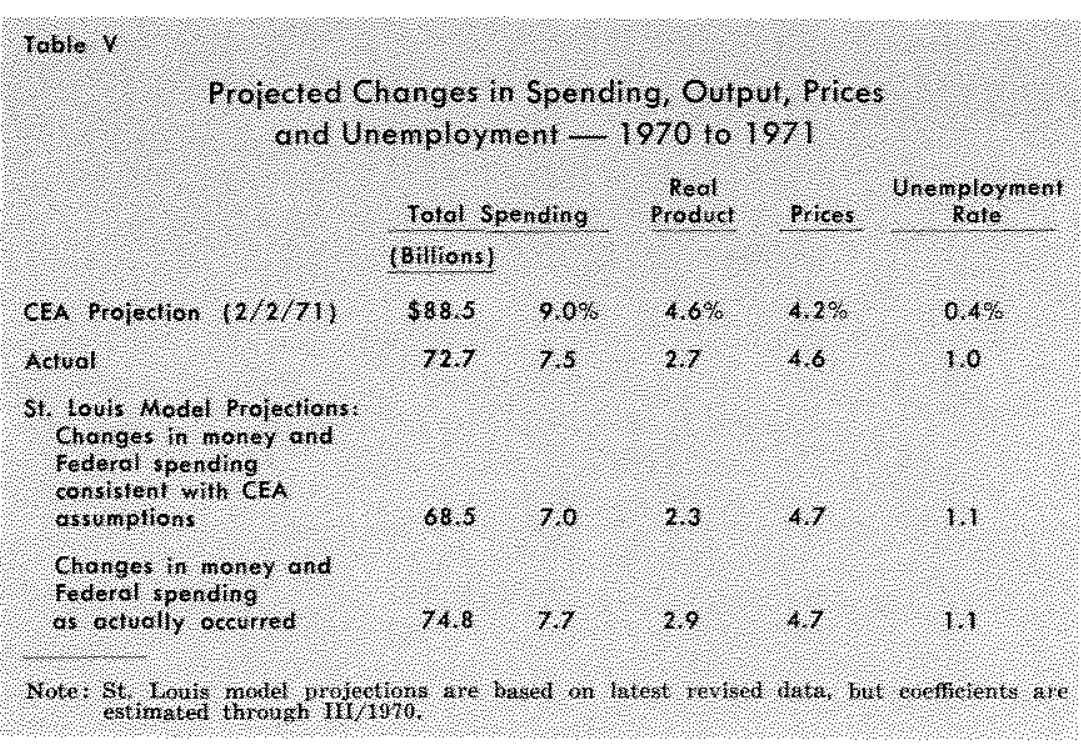

the CEA, even with their assumptions about the policy variables. Furthermore, even though the St. Louis model foresaw less buoyant total spending growth, it projected a more rapid increase in prices than the CEA, and thus substantially less expansion in real output.

The course of the major economic variables in 1971 was captured well by the St. Louis model, as indicated by the "ex post" simulation using actual money and
The St. Louis model indicates that the economy moved as expected in $1971 .^{10}$ The rate of inflation was being reduced, although slowly, and the growth of real product was accelerating. Even though unemployment was not declining in 1971, the stage was being set for reductions in the future. The pattern of monetary expansion, although irregular, provided a net stimulus to the economy in 1971 , and can be interpreted as having about the same economic impact as a steady 8 percent growth. ${ }^{11}$ However, the pattern of rapid monetary growth followed by essentially no growth has set the stage for a different set of problems for economic policy in 1972 than might otherwise have occurred with a steady growth rate.

\section{Economic Goals and Policy Plans for 1972}

The Administration has set targets of about a 5 percent rate of unemployment and a 2.5 to 3 percent

10It should also be noted that the economy noved in accord. ance with the "consensus" of economic forecasts in 1971 .

"See Keith M. Carlson, "Prolecting With the St. Louts Model: A Progress Report," this Review (February 1972), fn. 6, p. 24 . 
rate of inflation by the end of 1972 . These targets represent a substantially less optimistic view of basic economic forces than had been held by the Administration a year ago. Last year the Administration set targets of 4.5 percent unemployment and a 3 percent rate of inflation by mid-1972. To achieve the 1972 targets, the Administration projects an advance in total spending of 9.4 percent from calendar 1971 to 1972 , or slightly greater than the rate of increase projected for 1971. This section summarizes the Federal budget program for 1972 , considers monetary policy recommendations in the CEA Report, then evaluates the Administration's plan with the aid of the St. Louis model. ${ }^{12}$

\section{Federal Budget Program for 1972}

The budget plan for calendar 1972 calls for a relatively large fiscal stimulus. As estimated by this Bank, a deficit in the high-employment budget of $\$ 14.4$ billion is implied. ${ }^{13}$ Relative to $1969-1971$, the budget plan for 1972 is highly expansionary. Considering the size of the economy (as measured by potential GNP), the proposed fiscal stimulus for 1972 is about the same as experienced in 1967.

Expenditures - The budget plan includes a 13 percent increase in Federal expenditures on an NIA basis from calendar 1971 to 1972 . This increase would be up sharply from the 8.2 percent average rate of advance from 1969 to 1971 , but slightly below the 13.7 percent average rate of increase from 1965 to 1968.

Defense spending is projected to rise 6 percent in calendar 1972 , after declining at a 4.6 percent average rate from 1969 to 1971 . Nondefense spending, on the other hand, is planned to rise a very rapid 16 percent in 1972. This increase would follow increases of 16.1 percent in 1971 and 16.7 percent in 1970 . From 1965 to 1969 , nondefense spending increased at an 11 percent average rate. Projections of nondefense spending for 1972 include a pay raise for Government employees on January 1, a sharp increase in grants-in-aid to state and local govemments (general revenue sharing) retroactive to January 1 , a proposed increase in

\footnotetext{
12Rates of increase projected for certain economic variables are not stated explicitly in the 1972 CEA Report. Where such increases are discussed, they are based on estimates made by this Bank.

13The level of the surplus or deficit in the high-employnent butiget is subject to considerable variation, depending on the nature of the assumptions underlying its estimate. See "Technical Notes on Estmating the High-Employment Budget," available on request from this Bank.
}

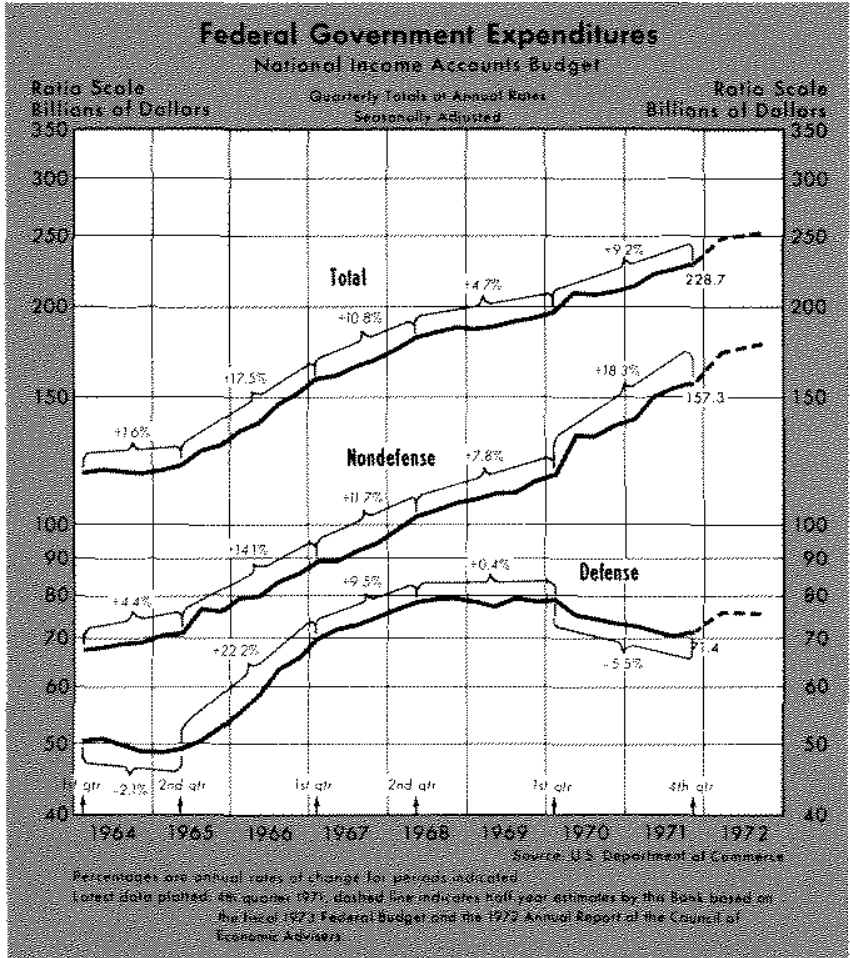

social security benefits, effective July 1 , and increased expenditures associated with a proposed reform of welfare programs.

Receipts - Federal receipts on an NIA basis are projected to rise by over $\$ 16$ billion in 1972 , or about 8.2 percent. This increase is expected to be large because incomes and profits are projected to advance rapidly.

When sources of receipts growth are considered, the GNP projections assume added importance. Table VI gives the sources of changes in receipts for 1972 . Tax changes tending to reduce receipts include: (1) the continuing effect of the Tax Reform Act of 1969; (2) the effect of the Revenue Act of 1971, affecting

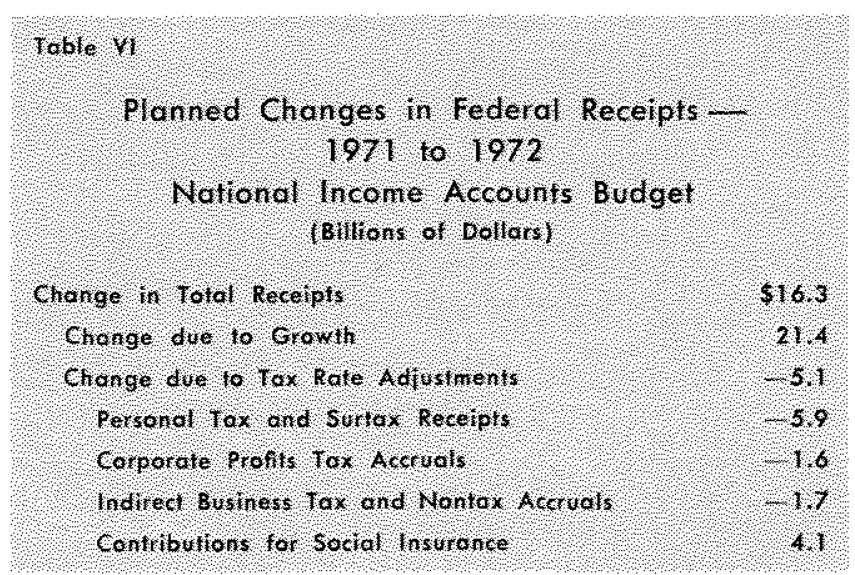


personal taxes via increased exemptions and deductions, corporate taxes through the job development tax credit, and excise taxes because of their removal from automobiles, and the suspension of the import surcharge. Changes in tax laws tending to increase tax receipts include: (1) expansion of the base for social security taxes from $\$ 7,800$ to $\$ 9,000 ;$ (2) a proposal for additional expansion of the base from $\$ 9,000$ to $\$ 10,200$; and (3) a revision toward less liberal depreciation allowances. The combined effect of these changes in tax laws results in a decrease of receipts of $\$ 5.1$ billion. Consequently, the projected $\$ 16.3$ billion increase in receipts implies a $\$ 21.4$ billion increase due to rapid economic expansion.

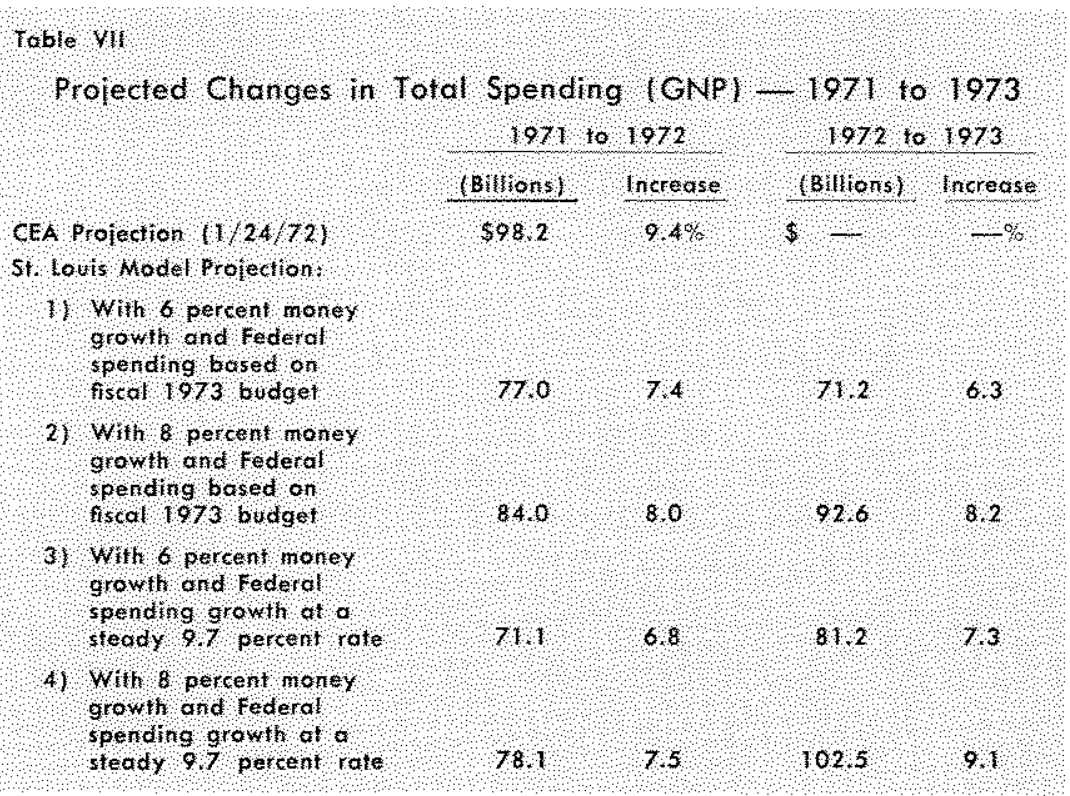

Surplus/deficit position - The combined effect of increased expenditures and receipts is an increase in the deficit to $\$ 36$ billion in calendar 1972 from $\$ 23$ billion in 1971. Since the NIA budget is influenced by the projected pace of economic activity, a better measure of the expected economic impact of the budget program is the high-employment budget.

On a high-employment basis (as estimated by this Bank), the NIA budget is projected to be in deficit by about $\$ 14$ billion in 1972 . The $\$ 14$ billion figure reflects an estimated $\$ 20$ billion rate of deficit in the first half and a $\$ 9$ billion rate in the second half. This fiscal stimulus for calendar 1972 is about the same as in 1967, when meastred relative to potential CNP. However, the planned 1972 fiscal stimulus has substantially different economic implications than the stimulus in 1967. The 1967 stimulus occurred when there was very little slack in the economy, and thus contributed importantly to the development of inflationary pressures. The proposed fiscal stimulus for 1972 comes at a time when there is considerable economic slack, suggesting that total demand for goods and services can be expanded substantially without reviving inflationary pressures.

\section{Nonetary Policy Recommendations}

The CEA again carefully avoids making any specific recommendations for monetary policy in 1972 . Monetary policy plays a definite role in the economic plan, however, as the CEA indicates that the GNP increase of 9.4 percent is based on the assump tion that the required monetary growth will be forthcoming. ${ }^{14}$

Though very general in their recommendations, the CEA does caution against extreme variations in the rate of change of the money stock.

A similar precept of steadiness with respect to monetary policy would also help to avoid inflationary excesses of demand. The problem is that there is no single measure or objective combination of measures of monetary policy that is a completely satisfactory or completely superior meastre of monetary policy by which a principle of steadiness could be calibrated. Judgment must be exercised. However, there is probably a presumption against extreme values or variations of the ate of change of narrowly defined money, i.e, currency plus demand deposits. 1.5

\section{Evaluetion Based on St. Louis Model}

The St. Louis model is used to focus on two considerations. (1) Is the projected increase in total spending consistent with the proposed stabilization policies?" (2) Are the price and unemployment goals consistent with the projected increase in total spending?

Feasibility of total spending goal - Table VII shows the results of the St. Louis model for the following four combinations of policies:

I) increases of Federal spending as proposed in the beldget and an expansion of money at a 6 percent annual rate;

141972 CEA Report, p. 26.

15lbid., p. 112.

16 For purposes of evaluation, steady growth rates for monev of 6 and 8 percent are assumed, These alternatives are illustrative and are in no way directly attributable to the CEA, or the Federal Reserve System. 
2) increases of Federal spending as proposed in the budget and an expansion of money at an 8 percent annual rate;

3) an increase of Federal spending at a steady 9.7 percent annual rate (this is the rate of increase of expenditures from second half 1971 to first half 1973) and an expansion in money at a 6 percent ammal rate; and

4) an increase of Federal spending a a steady 9.7 percent annual rate and an expansion of money at an 8 percent anmual rate.

According to the St. Louis model, the proposed budget policies would not yield an increase in total spending of 9 percent even if money grew at a rapid 8 percent rate. This conclusion reflects the properties of the St. Louis model with respect to the impact of fiscal stimali. According to the model, an acceleration of Federal spending has a positive impact on GNP for only two quarters, with the total effect receding to zero after 5 quarters. This property is in sharp contrast with other econometric models. Despite this substantial difference in the treatment of fiscal stimuli, the error in projecting GNP for the St. Louis model has averaged between $\$ 3$ and $\$ 4$ billion per year since 1965.

The combinations of policies in Table VII indicate that Federal spending based on the budget and 8 percent money growth would come closest to the CEA spending projection, though it would still fall short by a substantial amount. ${ }^{1 "}$ The combinations based on steady growth of Federal spending yield a lower total spending projection in 1972 than those based on an expenditure pattern as given in the budget. However, a steady growth in Federal spending would imply a stronger growth in $\mathrm{CNP}$ in 1973 than if the pattem evolves as projected in the budget.

Implications of total spending goal-As a step toward exmining the internal consistency of the Administration's overall economic plan, attention is focused on the price and amemployment projections. Without regard for how the total spending target is acheved, Table VIII on the following page shows the implied paths for real product, prices, and unemployment as given by the St. Louis model in comparison with the CEA. The St. Louis model result with 6 percent money growth is atso included for reference.

These comparisons are influenced by assumptions regarding the success of price-wage controls. The

\footnotetext{
"Given the proposed budget program, the St. Lous model indicates that a 12 percent rate of increase in money beginning first guarter 1972 wonld be required to acheve the CEA projection of a 9.4 percent fncrease in total spending in calendar 1972 , It should also be pointed out that GNP has glown as fast or faster fhan 9.4 percent in only one year (1960) out of the last twenty.
}

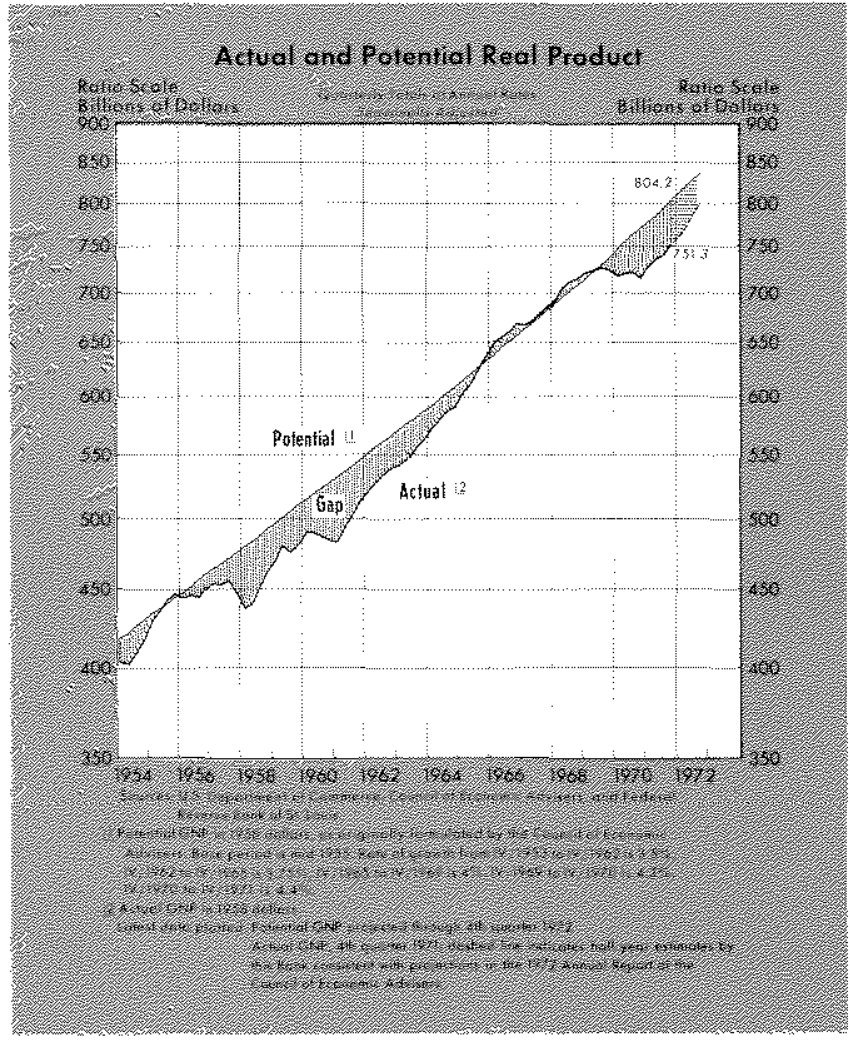

CEA has indicated considerable confidence in the controls, and has formed its targets with respect to prices, real product and unemployment accordingly. ${ }^{18}$ The St. Louis model does not incorporate explicitly any effect for price-wage controls, but focases instead on price trends in the absence of controls. St. Louis model projections of prices, which are not markedly different than those projected by the CEA, would suggest that the price-wage control program is not going to be subjected to great strains by the underlying course of monetary and fiscal actions.

The results for the year 1972 indicate that the St. Louis price projections are not markedly higher than the CEA's, even given their projected path for total spending. Where the difference may begin to appear significant is in 1973, though the CEA does not provide projections for calendar 1973. In other words, for 1972 the St. Louis projections for prices are roughly consistent with those projected by the $\mathrm{CEA}$ with a price-wage control program. The rate of inflation appears to be in the process of being reduced even in the absence of controls. It should be noted, however, that unless this implication is taken into account, there is a risk of setting the stage for severe strains on the price-wage control framework in 1973 if monetary and fiscal actions becone unduly expansive.

181972 CFA Report, p. 26. 


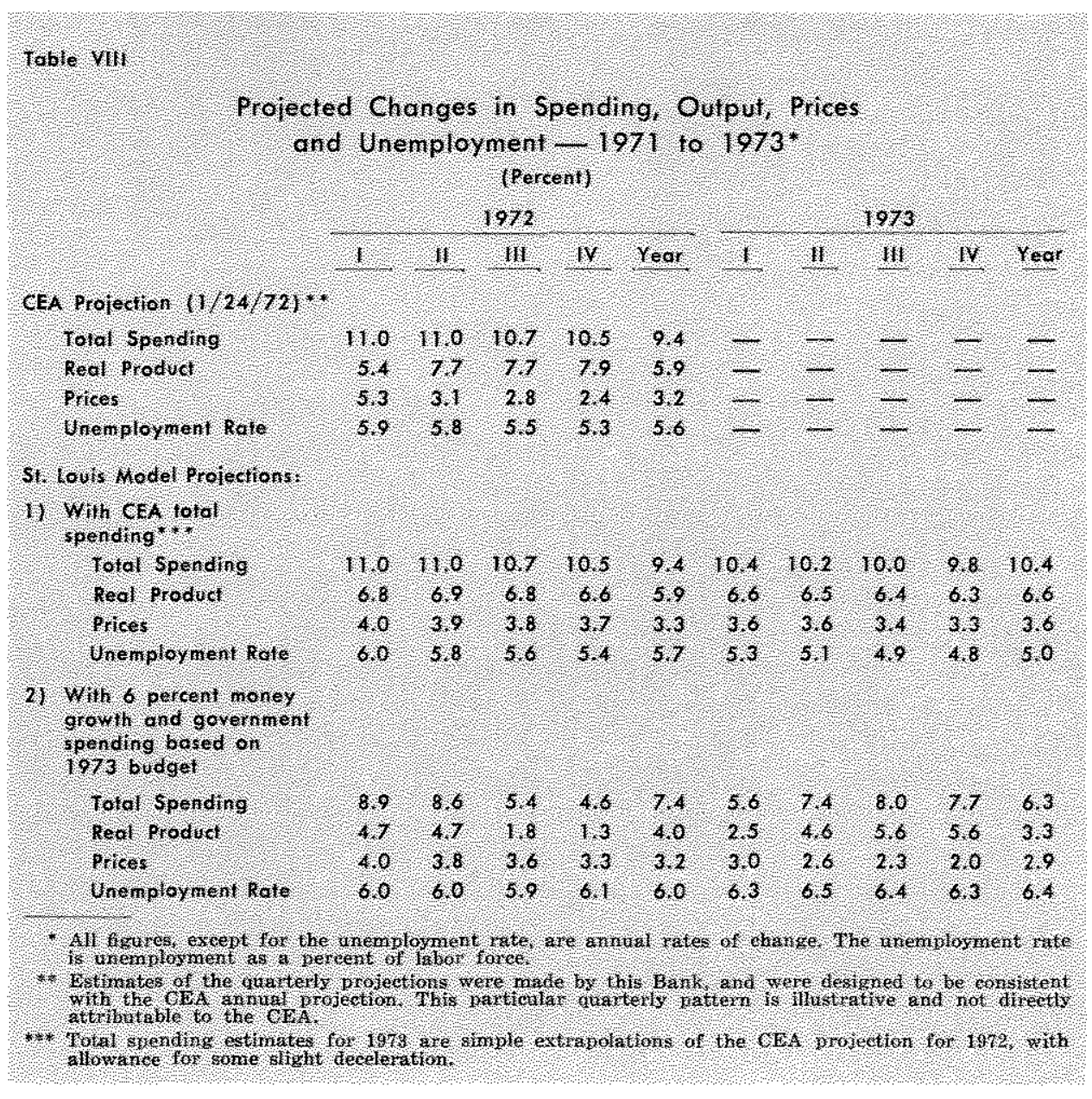

goals, a large fiscal stimulus to total spending has been proposed. Affirming a belief in the success of price-wage controls, the large advance in total spending is expected to be translated into faster real product growth and lower unemployment.

According to the St. Louis model, the projected increase in total spending is not consistent with the policy actions proposed by the Administration. If for some reason the targeted increase in total spending is achieved, the St. Louis model indicates that the 1972 goals for unemployment and prices are realistic. However, achievement of these goals in 1972 would have important implications for the course of economic activity after 1972. In particular, substantial employment gains in 1972 may be incurred at the cost of rekindling inflationary pressures in the future.
Given the CEA total spending goal and roughly comparable projections of prices, the St. Louis model indicates that unemployment will be reduced in 1972 . The rate of decline in unemployment is slightly less than projected by the CEA (the differences being minor).

\section{Summary}

The Administration has forecast that the U.S. economy will attain reductions in unemployment and inflation simultaneously in 1972. To achieve these
The economy is being confronted with a large fiscal stimulus. However, it is not so large as to prevent monetary actions from being controlled in such a way as to keep the economy on a sustainable path toward eventual attainment of full employment with relative price stability. With moderate monetary growth, the economic expansion will continue, although at a rate slower than projected by the Administration. The prospects for reducing inflation and phasing out price wage controls are good, if monetary expansion is maintained at a moderate rate.

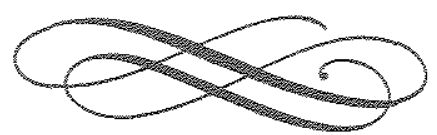

